\title{
Interactions of Medicines with Dietic Supplements
}

\author{
Kornelia W. Đaković Švajcer
}

\begin{abstract}
Department of Pharmacology, Toxicology and Clinical Pharmacology, Faculty of Medicine, University of Novi Sad, Novi Sad, Serbia
\end{abstract}

\section{SUMMARY}

Introduction: The widespread use of drugs in patients with different nutritional status, dietary habits, diet and dietary supplements creates an opportunity for the potentially unlimited numbers of interactions between medicines and food. Consequently, clinically significant manifestations of those interactions should not be ignored.

Corresponding section headings: Many drugs contain ingredients that react with the human organism in different ways. Dietary habits and lifestyle can sometimes significantly affect pharmacological properties of drugs. Interactions of drugs and dietary supplements can have a significant impact on the success of the therapy.

Conclusion: This kind of interaction is often forgotten when medication is prescribed, so the patient is usually not aware that eating habits, with given medication, can harm health. The result of these interactions in relation to the effects of drugs can be positive or negative, but it is often very significant.

Keywords: interactions, dietary supplements, drug metabolism, drug effects

\section{INTRODUCTION}

For years, the possibility of interaction between food and medicines has only occasionally been mentioned in top-level medical journals. It began with isolated reports, now more classic findings, such as the effect of lacking of vitamin $\mathrm{C}$ on the activity of barbiturates. Papers on the effect of isoniazid on vitamin B metabolism, causing its deficit have been published during 1950's [1]. Interaction of monoamine oxidase inhibitors used in depression therapy with food riched with biogenic amines (tyramine and histamine) was discovered in 1960. The result of this interaction was a significant increase in blood pressure and cerebrovascular insults [2]. In 1970 was found that calcium from foods, especially from dairy products, creates insoluble chelates with tetracycline and therefore interferes with their absorption. A similar reaction takes place with metals such as iron and copper [3]. At the end of the 1980s, there were noticed deaths due to ventricular arrhythmias in patients who used terfenadine and consumed grapefruit juice [4]. Due to the discovery that grapefruit juice contains components interfering with enzymes from the cytochrome P450 and other liver enzymes responsible for metabolizing almost $50 \%$ of drugs, interactions between food and medicines have attracted public attention, which has prompted a number of researches on the effect of food on drug metabolism $[5,6]$. Inspired with this discovery, the Joint Commission on Accreditation of Health Organizations (JCAHO) published in 1985 recommendations for examining all possible food and drug interactions that should be carried out before the drug is registered for the human use [7].

It is evident that many chronic dis- 
eases are multifactorial. In curing these diseases, a good therapeutic approach is the combination of medicines with adequate nutrition. As far as nutrition is concerned, there is an increasing number of functional foods and dietary supplements on the market, and for each of them is claimed to work on improving health. However, the potential dangers of using these products are not always overlooked [8]. These risks include increasing the risk of food-drug interactions due to an increase in the amount of specific functional ingredients in food, and encouraging self-medication that leads to poorer compliance with pharmacotherapy. The term "interaction" means a process in which one substance changes the effectiveness of the other, either by increasing or decreasing effect, or a new manifestation of the effect caused by neither one of the substances taking part in the process. This happens when two or more substances are consumed together, e.g. when one medicine is combined with another medicine or when the drug is taken with food, phytochemicals, etc., so medicines are not as effective as they should be and /or as it is expected. These interactions occur not only with medication prescribed by a doctor, but also with products purchased in free- sale, as well as with herbal, vitamin and mineral preparations. These interactions could be also clinically significant [9-12].

The risk of food and drug interactions is particularly high in elderly patients who usually use the majority of drugs. Particularly risky groups include malnourished patients, patients with malignant disorders and patients with impaired gastrointestinal tract function, immunocompromised deficiency patients, patients with transplanted organs, and patients on parenteral nutrition. Risky group of patients includes elderly people who take more than $30 \%$ of all drugs [13].

\section{CORRESPONDING TOPIC HEADINGS}

\section{Influence on kinetics and medicine dynamics}

The effect of the interactions of substances taken during drug therapy can be manifested in the change of one or more kinetic parameters (e.g. Tmax, Cmax, PIK0-inff).

The significance of these changes to the therapeutic response depends on the expression and duration of interaction, as well as the therapeutic extent of the drug $[9,10,14$ 16].

Various substances administered orally can have an effect on the pharmacodynamic effects of drugs as fallows:

1 . The effects of these substances are similar to the effects of drugs, and in this way they enhance their effect or toxicity (eg. thyramine, dopamine, and other vasoconstrictors in food enhance the toxic effects of MAO inhibitors such as, for example. tranylcypromine sulphate which can be fatal; coffee can increase the unwanted effects of theophylline-aminphfylline); 2. These substances may suppress medicines (e.g. vitamin $\mathrm{K}$ in food helps to create coagulation factors and acts opposite to warfarin; or caffeine as CNS stimulator reducing the anxiolytic effects of drugs) [17-21].

\section{Presystemic clearance}

Medicinal substance administered in various ways does not always reach the body in administered amounts. Biological availability is the percentage of the medicinal substance that has reached the systemic circulation in comparison the total amount of administered drug. Many drugs have low oral bioavailability, even if their absorption is complete. This is the result of a significant presystemic clearance. Presystemic clearance implies a meta-
Table 1. Changes in pharmacokinetic parameters of drugs during interactions

\section{Pharmacokinetic parameter}

\section{Actictivity}

Reducing the rate of absorption

Absorption

Forming a chelate complex with cations (Ca, Mg, Al, Fe, Zn)

Increase of absorption

Distribution Hypoalbuminemia $(<0.3 \mathrm{~g} / \mathrm{mL})$ in malnutrition or a low-protein diet

Metabolism Inhibition enzymes activity Induction of enzymes activity An influence on drug's tubular reabsorption

Excretion Decrease in $\mathrm{pH}$ value of urine 
bolic transformation of the drug after passing through the gastrointestinal tract and the liver before it enters the systemic circulation [9].

Many drugs have a small degree of oral bio-availability even though they are not degrading in the stomack. This is due to their potent bio-transformation during the first transit through the mucous membrane of the intestines and the liver. The strongest presystemic clearance is subject to the most commonly used lipophilic bases (eg. propranolol and amitriptyline). Presystemic clearance is almost never subject to lipophilic acids (e.g. salicylic acid and penicillin), unlike their esters (e.g.acetylsalicylic acid and pivampicillin), which are metabolized before entering the systemic circulation. The decrease in presystemic clearance during interactions with food, results in an increased biological availability of various lipophilic bases (propranolol, labetalol, metoprolol, hydralazine, erythromycin stearate, dicumurol, phenytoin, carbamazepine), which are pre-systemic metabolism includes hydroxylation, glucuronidation, or acetylation. In contrast, the bioavailability of lipophilic bases which undergo presystemic dealkylation (amitriptyline, codeine, dextropropoxyphene, prazosin, zimelidine) is unaffected by concurrent food intake [22].

The basic macromolecular structures, responsible for the presystemic clearance of drugs, are enzymes of the cytochrome family and transport proteins. CYP3A4/5, CYP2C8/9, CYP2D6, CYP1A2, CYP2C19 and CYP2E1 enzymes of the cytochrome family have the most important role in the metabolism of xenobiotics. CYP1A2 is an enzyme exclusively found in the liver. This enzyme inactivates caffeine, aromatic and heterocyclic amines. About $30 \%$ of cytochrome activity in the liver refers to CYP2C9. It's activity is significantly changed by Ginkgo biloba. CYP2C19 is primarily found in the liver, while CYP2D6 is an extrahepatic enzyme. CYP2E1 is found in the liver, lungs and brain and metabolizes organic solvents, for example, alcohol. CYP2E1 induction is due to chronic consumption of ethanol, as well as in the state of starvation. The activity of this enzyme inhibits broccoli, tea, onion, pepper, garlic and acute alcohol consumption. CYP3A4 metabolizes about 50\% of all drugs. Consequently, substances that induce or inhibit CYP3A4 are of particular significance for the drug interactions [9, 23-25].

The CYP3A4 enzyme, in addition to the liver is also found in the mucous membrane of the intestine, so some drugs are largely metabolized before they enter the systemic circulation. Food, or only some of its ingredients, can temporarily or in long-term change the activity of this enzyme, which leads to changes in the biological availability of certain drugs. Substances that reduce (inhibit) CYP3A4 activity as a rule increase the effects of some drugs. In contrast, substances that increase the activity of this enzyme reduce the effect of some drugs. However, in the case of drugs that pass into an active, therapeutically effective form in the body (e.g. enalapril) the effect of reducing or increasing the activity of CYP3A4 is opposite, i.e.reduction of enzyme activity also reduces the effects of the drug, and increasing the activity of the enzyme increases its effectiveness [26, 27].

P-glycoprotein (P-gp) is one of the cell transporters responsible for transporting many drugs through the cell membrane. P-gp was first discovered in malignant cells that was responsible for the citostatic resistance. However, P-gp is also found in healthy epithelial cells such as, for example, in the canalicular surface of hepatocyte, membrane cells of the proximal kidney tubule epithelium, and in the cillium enterocyte membrane. In these tissues P-gp plays a protective role; in intestines, $\mathrm{P}$-gp reduces the absorption of toxins from food and in the liver and kidneys it accelerates the elimination of toxins. In humans, P-gp is also found in endothelial cells of the bloodbrain barrier and in other tissues that possess a blood-tissue barrier such as placenta, ovary and testis, preventing various xenobiotics in circulation to enter these tissues. P-gp, located in the mucous membrane, prevents drug absorption; as the amount of this protein in the intestine is higher, a smaller amount of the drug is resorbed from the digestive tract in the body. On the other hand, if the activity of this protein is reduced, the amount of some drugs in the body is increased, and their function is increased. P-gp prevents absorption of drugs in the small intestine by releasing them from the cells [28-32].

The effects of drug interactions and other substances entering the body are not the same for all people. As each person has a unique fingerprint and DNA profile, it also has a unique cytochrome P450 profile. Pharmacokinetic properties of some drugs are different between males and females, as the result of 
Picture 1. Presystemic clearance of drugs with low bioavailability

A - After swallowing and transporting through the stomach, the drug from the small intestine is absorbed into the portal circulation 1 going into the liver 2 and then into the systemic circulation;

B - After entering the intestinal epithelial cells, one part is transported back to the lumen of the intestine (P-gp), one part is metabolized by the enzyme (CYP3A4), and the rest goes into the portal bloodstream;

C - the drug enters the hepatocytes from the portal bloodstream and one part of the drug is transported immediately into the gland (P-gp), part is metabolized by the (CYP3A4), and the non-metabolized part goes into systemic circulation.
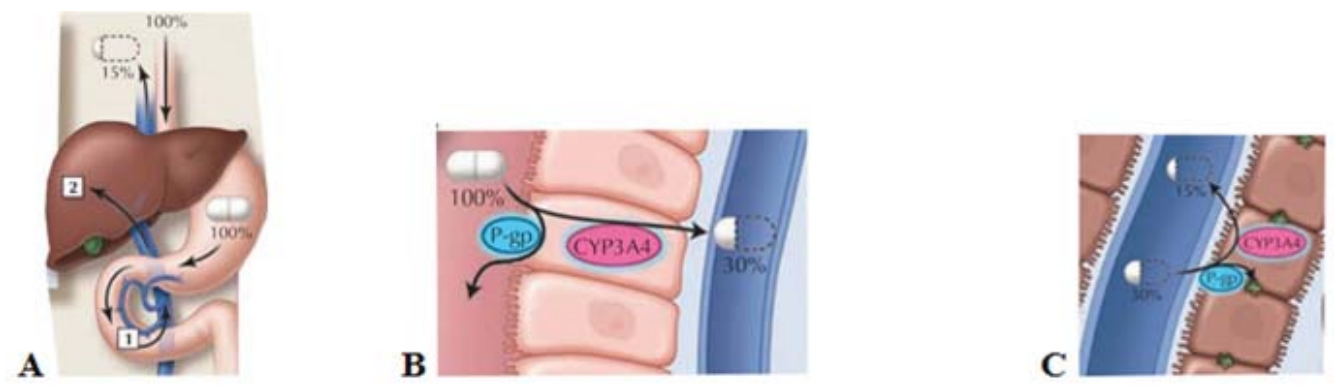

a variety in content of enzymes between males and females. Hence, for example, females have a higher content of liver CYP3A4, while differences in the content of CYP3A4, CYP3A5 and P-gp in the epithelium of the intestines were not found. Wolbold et al found that the level of liver's CYP3A4 in females was twice as high as in males [33]. As a result, verapamil clearance was increased in women by about $50 \%$ compared to men. Data confirms that women in the menstrual period, for still unclear reasons, have naturally a higher level of CYP3A4 in the body than men and the clearance of medications through these enzymes is more pronounced. An activity of intestinal CYP3A4 is lower by $20 \%$ in postmenopausal women compared to perimenopausal women [34].

\section{Interactions of medices and dietary supple- ments}

Dietary supplements or nutritional supplements are products that with their active ingredients could help, strengthen or promote the strengthening of the natural functions of the organism. The definition of supplements, as prescribed by the National Institute of Health of the United States is as follows: Supplement is any product (other than tobacco) intended to supplement the diet and contains one of the following components - vitamins, minerals, herbs or medical plants, their concentrates or extracts or their mixtures. Supplements can be vitamins (B complex, vitamins $\mathrm{A}, \mathrm{D}$ and $\mathrm{K}$, folic acid, biotin), minerals (magnesium, potassium, sodium, zinc, iron, copper), fatty acids (linoleic, linolenic, EPA, DHA, arachidonic, GLA, alpha lipoic), protein concentrates (milk, soybeans, amino acids), enzymes, plant extracts, live culture of microorganisms, and even conditionally hormones.' In the European Union, dietary supplements are defined as foods supplementing the usual diet. Regulations from 2010 on health safety of dietary products in the Republic of Serbia state the same definition of dietary supplements as in the European Union [35].

The use of vitamins, minerals and other supplements in the general population is constantly increasing. The study in Ireland showed that about $14 \%$ of the population uses both drugs and supplements at the same time. About $8 \%$ use medicines only with vitamins and minerals, about $4 \%$ of products without vitamins and minerals, and about $2 \%$ use both types of supplements.

Supplements in combination with drugs are most commonly used by women older than 75 years [36]. According to the data from an American literature, around 53\% to $73 \%$ of adults regularly use some dietary supplements. About $12 \%$ to $45 \%$ take drugs at the same time risking the interaction, and from $6 \%$ to $29 \%$ of these interactions are potentially dangerous and clinically significant [37-41]. Research of Sood et al. (2008) showed that about $40 \%$ of research subjects (out of 1795) used some of the dietary supplements [39].

A similar test was conducted in 2011 in Novi Sad. Two hundred eighty eight people were surveyed, aged between 41 and 60 years who purchased some of the herbal supplements in one of the pharmacies.

Most of the surveyed people had high or higher education. They used the supplements either on their own initiative or on the recommendation of acquaintances without medical education, without prior consultation with a physician or pharmacist. In percent, $88.9 \%$ of the surveyed people do not even think that using supplements should be known by their doctor. Most surveyed people (73.3\%) believe that preparations they use are safe even though 9.4\% do not know anything about these preparations. However, $40.3 \%$ of those surveyed believe that the use of these drugs with prescribed medication is not safe [42].

\section{Vitamins}

Since vitamins are considered safe, they are 
often taken uncontrollably and that can lead to interactions with medicines. Although vitamins are essential in everyday nutrition for maintaining health, they have the ability to influence the effects of some drugs. Some foods and supplements are additionally enriched with higher amounts of enzymes.

High doses of vitamin A with tetracycline antibiotics can cause intracranial hypertension. With anti-coagulant drugs, vitamin A can cause hemorrhage [43].Vitamin B complex reduces tetracycline absorption and reduces its effectiveness. Vitamins B2 (riboflavin) and B6 (pyridoxine) increase the effects of tricyclic antidepressants.

Vitamin B3 (niacin) combined with oral anticoagulants can lead to hemorrhage. Vitamin B6 reduces the effectiveness of antiepileptics. Vitamin B9 (folic acid) reduces the effectiveness of phenytoin and other anticonvulsant drugs [43].

High doses of vitamin $\mathrm{C}$ increases absorption of paracetamol and non-steroidal anti-inflammatory drugs and reduce their elimination through urine. Thus, the effect of these drugs is enhanced as well as their side effects.

Vitamin C is responsible for aluminum absorption. Manifestations of aluminum poisoning may occur if it is administered with antacids that contain aluminum. Vitamin C also increases the level of tetracyclines in the body. Tetracyclines become more effective, but the risk of their side effects is also increased [43].

Vitamin D enhances the function of doxorubicin. It also reduces the absorption of tricyclic antidepressants, beta blockers, and chlorpromazine [43].

Vitamin $\mathrm{K}$ is a necessary for the body to maintain normal blood coagulation function, but it neutralizes anticoagulant effect of warfarin. Vitamin $\mathrm{K}$ is found in large quantities in broccoli, Savoy cabbage, parsley, spinach, Brussels sprout, but also in coffee, green tea and liver [43].

Due to its antioxidant effects, vitamin E is often used as a supplement. Since vitamin E improves circulation, the effect of anticoagulants and antiplatelet drugs can be increased. A patient using vitamin $\mathrm{E}$ before the therapy begins should not stop using vitamin $\mathrm{E}$, since therapy with anticoagulants is titrated according to the effect. However, it is very important not to start taking vitamin $\mathrm{E}$ during therapy, nor to stop its use abruptly. Vitamin $\mathrm{E}$ is found in larger quantities in walnuts, various seeds and oil. Warfarin interactions with food supplements are often accompanied by very serious symptoms. Literature describes spinal epidural hematoma, spontaneous intracerebral hemorrhage, retrobulbar hemorrhage, subarachnoid hemorrhage, spontaneous hyphaema (hemorrhage in the anterior chamber of the eye) and post-operative bleeding [43].

Vitamin A, C and E cocktails have been described to reduce the effectiveness of mebendazole [43].

\section{Minerals and calcium}

Minerals can form complexes or chelation with drugs which are insoluble compounds that can't be practically resorbed. Iron and other minerals such as copper, zinc, manganese and magnesium inhibit quinolone's absorption by forming insoluble complexes in the intestine [43].

In vitro, Ranitidine interacts with calcium ions $\left(\mathrm{Ca}^{++}\right)$, magnesium $\left(\mathrm{Mg}^{++}\right)$and iron $\left(\mathrm{Fe}^{++}\right)$in simulated physiological conditions. Copper ion $\left(\mathrm{Cu}^{++}\right)$and iron $\left(\mathrm{Fe}^{++}\right)$interact with levothyroxine [44].

Magnesium salts may, in combination with aminoglycoside antibiotics (amikacin, gentamicin, kanamycin, tobramycin, streptomycin), increase their side effects on skeletal muscles. Magnesium binds to fluoroquinolones (ciprofloxacin, enoxacin, norfloxacin, sparfloxacin) and simultaneously reduces their absorption. In addition to these antibiotics, magnesium significantly interferes with the absorption of bisphosphonates (alendronate, etidronate, clodronate, etc.) and digoxin. In contrast, magnesium enhances absorption of sulfonylureas (carbutamide, chlorpropamide, tolbutamide, glyclazide, etc.) and the result may be severe hypoglycemia. Magnesium hydroxide increases ibuprofen absorption, most likely due to an increase in $\mathrm{pH}$ in the stomack. Since it prevents the entry of calcium into myocardial cells, magnesium reacts synergistically with calcium channel blockers (nifedipine, verapamil, diltiazem, amlodipine, felodipine, etc.). The result of this interaction is a potent hypotension [43]. It is known that calcium interacts with some antibiotics. Orange juice supplemented with calcium may lead to the formation of chelate with fluoroquinolones (ciprofloxacin, gatifloxacin, levofloxacin) and tetracyclines (tetracycline, minocycline). The 
administration of levofloxacin with food-rich calcium significantly reduces its bioavailability [45]. Calcium also prevents the bisphosphonate absorption. Due to preventing absorption, calcium also reduces the effectiveness of sotalol. Calcium carbonate, which can be found in various supplements and antacids (OTC drugs), interferes with levothyroxine and prevents its absorption. Such preparations should be taken at least one hour before or after the medicine. Benzodiazepines significantly inhibit the transport of calcium into the nerves of the brain, heart cells and another tissues. Alterations in the balance of calcium are associated with anxiety, fear, panic attacks, and muscle cramps, since calcium modifies the effects on GABA receptors. Calcium irritates GABA receptors, and only small doses in combination with vitamins (but not calcium from natural foods) can cause increased stimulation of the central nervous system and anxiety, insomnia and fear. Calcium provokes pharmacodynamic antagonism with calcium channel blockers (diltiazem, verapamil). Some diuretics (chlortiazide, hydrochlorothiazide, indapamide, chlortalidone) may increase the level of calcium in the body. Supplementation of calcium in the patients treated with thiazide diuretics can lead to the formation of kidney stones [43].

\section{Melatonin}

Melatonin is a hormone that naturally occurs in the body. In addition, melatonin is used in the treatment of insomnia and for regulation of the disturbed natural circadian rhythm. Contraceptives and fluvoxamine, increase the level of melatonin in the body and in combination with exogenous melatonin can cause drowsiness. Melatonin enhances the sedative effects of benzodiazepine, hypnotics and antidepressants $[43,46]$.

In combination with melatonin, the biotransformation of drugs that are substrates for CYP2C19 (amitriptyline, citalopram, diazepam, lansoprazole, omeprazole, phenytoin, warfarin) is inhibited, and there is a possibility of side-effect reactions to these drugs [43, 46]. Since it strengthens the immune system, melatonin reduces the function of immunosuppressors used in organ transplantation (cyclosporine, tacrolimus, sirolimus and corticosteroids) and can lead to rejection of transplants $[43,46]$.

Melatonin may increase the fre- quency of convulsions, especially in children. In combination with drugs that reduce the threshold for the formation of convulsions (propofol, mexiletine, amphotericin, penicillin, cephalosporins, imipenem, bupropion, cyclosporin, fentanyl, theophylline, etc.) melatonin can enhance their side effects. The activity of anticonvulsant drugs (phenobarbital, primidone, valproic acid, gabapentin, carbamazepine, phenytoin and others.) can be reduced and the incidence of epileptic seizures can be increased [43, 46].

If melatonin is used with substances antiplatelet properties (aspirin, clopidogrel, diclofenac, ibuprofen, naproxen, dalteparin, enoxaparin, heparin, nadroparin and warfarin) it can lead to uncontrolled hemorrhage $[43,46]$.

\section{Omega-3 fatty acids}

Omega-3 fatty acids are found in large quantities in fish. Isolated omega- 3 fatty acids are often used on a daily basis as supplements. They reduce elevated blood pressure and in combination with antihypertensive drugs (captopril, enalapril, losartan, valsartan, diltiazem, amlodipine, hydrochlorothiazide, furosemide, etc.) can lead to severe hypotension [43].

Also, omega-3 fatty acids increase the activity of drugs preventing blood coagulation (aspirin, clopidogrel, diclofenac, dipyridamole, ibuprofen, naproxen, dalteparin, enoxaparin, heparin, nadroparin, warfarin) and a combination with these drugs may result in uncontrolled bleeding [43].

\section{Inositol}

Inositol is thought to be one of the vitamins B (B8). Inositol inhibits the release of serotonin into the nerve cells as well as antidepressants from the group of specific serotonin reuptake inhibitors. Therefore, it exhibits an antidepressant effect and reacts in synergy with antidepressants [46].

\section{Coenzyme Q-10}

Coenzyme Q-10 (CoQ10) is increasingly used as a dietary supplement and today it is one of the most common dietary supplements. It inhibits intestinal P-gp and leads to increased absorption of drugs from the gastrointestinal tract.

CoQ10 lowers blood pressure, and in combination with antihypertensive drugs (captopril, enalapril, losartan, valsartan, diltiazem, 
amlodipine, hydrochlorothiazide, furosemide, etc.) can lead to dangerous hypotension. It also significantly reduces the effect of warfarin and coumarin derivatives [43].

In experiments on animals, the pretreatment with CoQ10 over 5 consecutive days led to changes in the pharmacokinetic parameters of theophylline. The time to achieve maximum plasma concentrations is significantly prolonged. The maximum concentrations of theophylline in plasma and AUC concentration were increased by about $100 \%$ [47].

\section{Quercetin}

Quercetin is a food ingredient that increases plasma antioxidant capacity and thus prevents the onset of atherosclerosis, but also inhibits some stages of cancer development. The use of foods rich in quercetin is an alternative complementary treatment in patients receiving steroid therapy in the case of testosterone deficiency or in breast cancer, as this substance changes the metabolic process of natural steroids and their metabolites. Quercetin is a supplement used as a self-medicament for benign prostatic hyperplasia, since it is known that it causes vasodilation. As for the drugs, tamsolusin is often used in the treatment of benign prostatic hyperplasia. Tamsulosin alone can lead to orthostatic hypotension since it causes vasodilation of blocking a1-adrenergic receptors. These two substances react synergistically and can lead to a very strong and life-threatening hypotension [48].

Quercetin is found in tea, apples, onion, St. John 's wort (Cantarion) and grapefruit juice. It is a potent inhibitor of CYP2C19 and CYP3A4, and a moderate CYP2D6 inhibitor [49]. Quercetin can potentially affect P-gp in the blood-brain barrier at higher doses [50].

\section{Resveratrol}

Resveratrol is a natural polyphenol, often used as a supplement in foods. Various positive effects are attributed to it, such as cardioprotective function, immunomodulation and antitumor function. In healthy people who do not use drugs, the resveratrol is very well tolerated. Resveratrol shows an effect on various isoenzymes of cytochrome P450 and may change the pharmacokinetics of various drugs, especially if taken in high doses. Resveratrol can reduce the first pass metabolism and lead to more exposure of the body to various simultaneously prescribed drugs [51].
Resveratrol found in red wine and peanuts, inhibits platelet aggregation. If taken with anticoagulants, fatal hemorrhaging may occur [52].

Green tea extract and grape seed extract (the active ingredient is resveratrol) in vitro inhibited the activities of liver CYP2C9, CYP2D6 and CYP3A4. After 7 days of continuously administrating these extracts, the elimination of i.v. administered midazolam was significantly accelerated, indicating the induction of hepatic CYP3A4. After oral administration of midazolam to animals that received subchronic intake of green tea extract (for 7 days), $\mathrm{C}_{\text {max }}$ and AUC0- $\infty$ were increased, which is most likely due to the inhibition of CYP3A4 in the colon wall [53].

Red wine, which also contains the mixture of flavonoids and other polyphenolic components, inhibits CYP3A4 in vitro. White wine does not possess this kind of inhibitory potential. By inhibiting the cytochrome $\mathrm{P} 450$ system, resveratrol can increase the toxicity of statins, calcium channel blockers, HIV protease inhibitors, immunosuppressants, antihistamines, benzodiazepines, and drugs used in the treatment of sexual dysfunction. However, such drastic action can be expected when using resveratrol as a supplement but not in consuming a glass of red wine daily. Some experimental data show that resveratrol besides CYP3A4 inhibits MRP2 (multidrug resistance protein 2) due to the effectiveness of some drugs, such as increased carbamazepine [51].

Food polyphenols (resveratrol, quercetin, rutin) have antioxidant properties. In addition to other activities, they also showed protective effects on the damage of mitochondrial function induced by indomethacin [54]

\section{Glucosamine}

Glucosamine is a dietary supplement that helps in strengthening the joint structure and is used in osteoarthritis therapy. When administered simultaneously with drugs that prevent blood coagulation (vitamin $\mathrm{K}$ antagonists, heparin, aspirin, clopidogrel, ibuprofen and naproxen) it can lead to severe hemorrhaging. Clinical studies describe an increase of INR after initiating glucosamine therapy in a patient who has chronically used warfarin [55]. Glucosamine can increase the activity of insulin and lead to hypoglycemia. This substance also reduces the analgesic effect of paracetamol. Etoposide, topoisomerase II and doxorubicin are less ef- 
fective in the presence of glucosamine, given that it prevents the entry of drugs into malignant cells. Glucosamine increases furosemide side effects [56].

\section{L-Carnitine}

L-carnitine is an amino acid that is normally synthesized in the body. The role of L-carnitine is to provide energy to the body. L-Carnitine is used in elderly people with memory problems, people who have suffered a stroke, a person with diabetic neuropathy, a deficiency of testosterone, and Alzheimer's disease.

The effectiveness of acenocoumarol and warfarin is enhanced by taking L-carnitine and there is a risk of hemorrhaging [56].

\section{Menthol}

In vitro, studies have shown that peppermint, menthol, ether oil from the mint plant and mint-tea are reversible inhibitors of hepatic CYP3A4. When aspirin, ibuprofen, diclofenac, naproxen are taken along with them, spontaneous bleeding may occur, which may even be fatal [57]. Menthol enhances the action of nifedipine, felodipine and some antibiotics and inhibits the activity of cyclosporine $[58,59]$.

\section{Beta-Sitosterol}

$\beta$ - sitosterol is an active substance from various plants such as bur and heather. It is structurally similar to cholesterol. Many drugs change sitosterol kinetics, but sitosterol interacts with drugs for the treatment of hypercholesterolaemia and benign prostatic hyperplasia [46].

\section{Beta-glucan}

Beta-glucan is a polysaccharide which is found in plants and cereals. In addition, it can be found in beer yeast and some mashrooms. When foods rich in $\beta$-glucan are administered with non-steroidal antiinflammatory (e.g.indomethacin), medicines have side effects on the gastrointestinal tract and can cause stomach and duodenal hemorrhage [60].

Beta-glucan can lead to severe hypotension if used with high blood pressure therapy (captopril, enalapril, losartan, valsartan, diltiazem, amlodipine, hydrochlorothiazide and furosemide) [43].

Beta-glucan strengthens the immune system but reduces the function of immunosuppressors (azathioprine, cyclosporin, tacrolimus, sirolimus, prednisone and corticosteroids) [43].

\section{Beta-carotene}

Beta-carotene with selenium, vitamin $\mathrm{C}$ and vitamin $\mathrm{E}$ can reduce the effectiveness of drugs used in the treatment of hypercholesterolemia (atorvastatin, fluvastatin, lovastatin and pravastatin) [43].

\section{Anthocyanins}

Anthocyanins are the largest and most important group of water-resistant plant pigments. They are widely used in human nutrition since they are found in vegetables, fruits and red wine. Many medicinal properties of these substances are associated with their antioxidant potential. However, they can also be the cause of unexpected reactions to drugs that are simultaneously used [61].

\section{Stevia}

Stevia (Stevia rebaudiana Bert.) is a South American medicinal herb that is unique in its naturally sweet leaves. The natives use this plant for more than 1500 years as a natural and healthy sweetener. In addition, it was used in people with diabetes and increased blood pressure.

Stevia is diuretic and lithium excretion is reduced. In people receiving lithium for therapeutic purposes, the interaction of stevia and lithium leads to very difficult side effect reactions. In combination with anti-diabetics, Stevia can cause hypoglycemia [43].

\section{Turmeric}

The active turmeric ingredient, polyphenol curcumin is used as spice, but also as dietary supplement. Curcumin inactivates CYP3A4 and P-gp and therefore interacts with many drugs that are the substrate for this protein $[62,63,64]$.

Turmeric reduces the activity of paracetamol and talinolol. In combination with turmeric, following effects are increased: the effects of acetylcholinesterase inhibitors, amiloride, anticoagulants and antiplatelet drugs, oral anti-diabetics, NSAIDs, antilipemics, antihistamines, antidepressants, cardiovascular drugs, erythromycin, erythropoietin, norfloxacin and retinol $[59,65,66]$.

\section{CONCLUSION}

Herbal and nutritional supplements are increasingly used, especially in the female population and in the elderly. The risks from the 
interactions of these substances with drugs being taken are at the same time large, and the consequences are not always easy to predict. Doctors are usually not aware of what dietary supplements are used by patients, given that they are taken on their own initiative, and patients themselves do not usually inform doctors about taking these substances.

Most systematic literature reviews have shown that the interactions of dietary supplements and drugs are moderately difficult or mild. However, some dietary supplements interact with drugs that pose serious health threats. Because of the limited quality and lack of primary data, these data should be treated with caution [67].

\section{REMARK}

This paper is based on parts of the book: Kornelia Đaković Švajcer. MEĐUDELOVANJA LEKOVA, HRANE I SUPLEMENATA/INTERACTIONS OF MEDICINAL PRODUCTS, FOOD AND SUPPLEMENTS. (on Serbian), Alfagraf, Petrovaradin, 2016.

\section{REFERENCES}

1. Cahn J, Boucher, Pierre R. Experimental studies on neurologic toxicity of isoniazid; preventive measures. Therapie. 1953; 8(1):62-4.

2. Burford H, Leick J, Walaszek EJ. Modification of the effects of biogenic amines on the heart by iproniazid. Arch Int Pharmacodyn Ther. 1960; 128:3950.

3. Stokstad EL, Pensack JM, Huhtanen CN. The effect of calcium salts on chlortetracycline absorption. Antibiot Annu. 1959-1960; 7:879-83.

4. Benton RE, Honig PK, Zamani K, Cantilena LR, Woosley RL. Grapefruit juice alters terfenadine pharmacokinetics, resulting in prolongation of repolarization on the electrocardiogram. Clin Pharmacol Ther. 1996; 59(4):383-8.

5. Kirk Jk. Significant drug-nutrient interactions. Am Fam Physician. 1995; 51(5):1175-82.

6. Cardona Pera D. Drug food interactions. Nur Hosp. 1999; 14(Suppl 2):129S-40S.

7. 1994 Accreditaion Manual for Hospitals. Vpl 11. Scoring guidelines. Oakbrook Terrace, Ill.: Joint Commission on Accreditation of Health Care Organisation 1993; 2:8.

8. Ohnishi N, Yokoyama T. Interactions between medicines and functional foods or dietary supplements. Keio J Med. 2004; 53(3):137-50.
9. Daković Švajcer K. Osnovi farmakologije/Pharmacology's base. Ortomedics, Novi Sad, 2010. On Serbian.

10. Đaković-Švajcer K. Food and drugs - Editorial. Med. Pregled 2002; 55(1-2):5-12.

11. Daković-Švajcer K, Sabo A, Jakovljević V, Mikov M, Tomić Z, Rašković A, Horvat O, Popović J, Samojlik I, Vukmirović $S$, Milijašević B. The influence of food on lansoprazole pharmacokinetics. 9th World Conference on Clinical Pharmacology and Therapeutics, Quebec 2008, Can J Clin Pharmacol 2008; 15:e460.

12. Samojlik I, Đaković-Švajcer K, Božin B, Mikov $M$. Herb-drug interactions: the influence of essential oil of caraway (Carum carvi L.) on the pharmacokinetics of paracetamol. BMC Pharmacol Toxicol 2012; 13(Suppl 1):A27.

13. Webb D. When Foods and Drugs Collide - Studies Expose Interactions Between Certain Foods and Medications. Today's Dietitian 2010; 12(12):26.

14. Mason P. Drug-food interactions (1) Food and medicines. Pharmaceutical J. 2002; 269:571-3.

15. Reppas C, Eleftheriou G, Macheras P et al. Effect of elevated viscosity in the upper gastrointestinal tract on drug absorption in dogs. Eur J Pharm Sci 1998; 6:131-9.

16. Tanno FK, Sakuma S, Masaoka Y et al. Site-specific drug delivery to the middle-tolower region of the small intestine reduces food-drug interactions that are responsible for low drug absorption in the fed state. J Pharm Sci 2008;

17. Ge F, Zeng F, Liu S, Guo N, Ye H, Song Y, Fan J, Wu X, Wang X, Deng X, Jin Q, Yu L. In vitro synergistic interactions of oleanolic acid in combination with isoniazid, rifampicin or ethambutol against Mycobacterium tuberculosis. J Med Microbiol. 2010; 59(Pt 5):567-72.

18. Morinaga S, Kawasaki A, Hirata H, Suzuki S, Mizushima Y. Histamine poisoning after ingestion of spoiled raw tuna in a patient taking isoniazid. Intern Med. 1997; 36(3):198-200.

19. Stewart MM. MAOls and food-fact and fiction. J Hum Nutr. 1976; 30(6):415-9.

20. Taylor SL. Histamine food poisoning: toxicology and clinical aspects. Crit Rev Toxicol. 1986; 17(2):91-128.

21. Uragoda CG. Histamine poisoning in tuberculous patients after ingestion of tuna fish. Am Rev Respir Dis. 1980; 121(1):157-9.

22. Melander A, McLean A. Influence of food intake on presystemic clearance of drugs. Clin Pharmacokinet. 1983; 8(4):286-96.

23. Harris RZ, Jang GR, Tsunoda S. Dietary effects on drug metabolism and transport. Clin Pharmacokinet. 2003; 42(13):1071-88. 
24. Bhardwaj RK, Glaeser H, Becquemont L, Klotz U, Gupta SK, Fromm MF. Piperine, a major constituent of black pepper, inhibits human P-glycoprotein and CYP3A4. J Pharmacol Exp Ther. 2002; 302(2):645-50.

25. Ho BE, Shen DD, McCune JS, Bui T, Risler L, Yang Z, Ho RJ. Effects of Garlic on Cytochromes P450 2C9- and 3A4-Mediated Drug Metabolism in Human Hepatocytes. Sci Pharm. 2010; 78(3):473-81.

26. Hellum $\mathrm{BH}, \mathrm{Hu} Z$, Nilsen OG. The induction of CYP1A2, CYP2D6 and CYP3A4 by six trade herbal products in cultured primary human hepatocytes. Basic Clin Pharmacol Toxicol. 2007; 100(1):23-30.

27. Hellum BH, Hu Z, Nilsen OG. Trade herbal products and induction of CYP2C19 and CYP2E1 in cultured human hepatocytes. Basic Clin Pharmacol Toxicol. 2009; 105(1):58-63.

28. Fricker G, Drewe J, Huwyler J, Gutmann H, Beglinger $C$. Relevance of $p$-glycoprotein for the enteral absorption of cyclosporin $\mathrm{A}$ : in vitro-in vivo correlation. Br J Pharmacokinet. 1997; 118:1841-7.

29. Holtzman CW, Wiggins BS, Spinler SA. Role of P-glycoprotein in statin drug interactions. Pharmacotherapy. 2006; 26(11):1601-7.

30. Matheny CJ, Ali RY, Yang X, Pollack GM. Effect of prototypical inducing agents on P-glycoprotein and CYP3A expression in mouse tissues. Drug Metab Dispos. 2004; 32(9):1008-14.

31. Abuznait AH, Qosa H, O'Connell ND, AkbarianTefaghi J, Sylvester PW, El Sayed KA, Kaddoumi A. Induction of expression and functional activity of P-glycoprotein efflux transporter by bioactive plant natural products. Food Chem Toxicol. 2011; 49(11):2765-72.

32. Zhou S, Lim LY, Chowbay B. Herbal modulation of P-glycoprotein. Drug Metab Rev. 2004; 36(1):57104.

33. Wolbold R, Klein K, Burk O, Nüssler AK, Neuhaus $P$, Eichelbaum M, Schwab M, Zanger UM. Sex is a major determinant of CYP3A4 expression in human liver. Hepatology 2003; 38:978-88.

34. Paine MF, Ludington SS, Chen M-L, Stewart PW, Huang $S-M$, Watkins PB. Do men and women differ in proximal small intestinal CYP3A or p-glycoprotein expression? Drug Metab Dispos. 2005; 33:426-33.

35. Novaković B, Torović Lj (ed). Bromatologija: nutritivna vrednost $\mathrm{i}$ bezbednost hrane. Novi Sad, Medicinski fakultet, 2014.

36. Peklar J, Henman MC, Kos M, Richardson K, Kenny RA. Concurrent use of drugs and supplements in a community-dwelling population aged 50 years or more: potential benefits and risks. Drugs Aging. 2014; 31(7):527-40.

37. Peng CC, Glassman PA, Trilli LE, Hayes-Hunter J, Good CB. Incidence and severity of potential drugdietary supplement interactions in primary care patients: An exploratory study of 2 outpatient practices. Arch Intern Med. 2004; 164(6):630-6.

38. Lee AH, Ingraham SE, Kopp M, Foraida MI, Jazieh $A R$. The incidence of potential interactions between dietary supplements and prescription medications in cancer patients at a Veterans Administration hospital. Am J Clin Oncol. 2006; 29(2):178-82.

39. Sood A, Sood R, Brinker FJ, Mann R, Loehrer LL, Wahner-Roedler DL. Potential for interactions between dietary supplements and prescription medications. Am J Med. 2008; 121(3):207-11.

40. Loya AM, GonzÂlez-Stuart A, Rivera JO. Prevalence of polypharmacy, polyherbacy, nutritional supplement use and potential product interactions among older adults living on the United StatesMexico border: A descriptive, questionnaire-based study. Drugs Aging. 2009; 26(5):423-36.

41. Timbo BB, Ross MP, McCarthy PV, Lin C-TJ. Dietary supplements in a national survey: Prevalence of use and reports of adverse events. J Am Diet Assoc. 2006; 106(12):1966-74.

42. Samojlik I, Mijatović V, Gavarić N, Krstin S, Božin B. Consumers' attitude towards the use and safety of herbal medicines and herbal dietary supplements in Serbia. Int J Clin Pharm. 2013; 35:835-40.

43. RxList.com. San Clemente, California; c2017 [cited 2016 Dec 27]. Available from: https://www. rxlist.com

44. Sridevi N, Yusuff KK. Rapid in vitro screening of drug-metal ion interactions. Toxicol Mech Methods. 2007; 17(9):559-65

45. Amsden GW, Whitaker AM, Johnson PW. Lack of bioequivalence of levofloxacin when coadministered with a mineral-fortified breakfast of juice and cereal. J Clin Pharmacol. 2003; 43(9):990-5.

46. MedlinePlus. U.S. National Library of Medicine; c2017 [cited 2016 Dec 27]. Available from: https: // www.nlm.nih.gov/medlineplus

47. Baskaran R, Shanmugam S, Nagayya-Sriraman S, Kim JH, Jeong TC, Yong CS, Choi HG, Yoo BK. The effect of coenzyme Q10 on the pharmacokinetic parameters of theophylline. Arch Pharm Res. 2008; 31(7):938-44.

48. Vrolijk MF, Haenen GR, Opperhuizen A, Jansen EH, Schiffers PM, Bast A. The supplement-drug interaction of quercetin with tamsulosin on vasorelaxation. Eur J Pharmacol. 2015; 746:132-7.

49. Rastogi H, Jana S. Evaluation of inhibitory effects of caffeic acid and quercetin on human liver cytochrome p450 activities. Phytother Res. 2014; 28(12):1873-8.

50. Weber CC, Kressmann S, Fricker G, Müller WE. Modulation of P-glycoprotein function by St John's wort extract and its major constituents. Pharmacopsychiatry. 2004; 37(6):292-8. 
51. Detampel P, Beck M, Krähenbühl S, Huwyler J. Drug interaction potential of resveratrol. Drug Metab Rev. 2012; 44(3):253-65.

52. Bertelli AA, Giovannini L, Giannessi D, Migliori M, Bernini W, Fregoni M, Bertelli A. Antiplatelet activity of synthetic and natural resveratrol in red wine. Int J Tissue React. 1995; 17(1):1-3.

53. Nishikawa M, Ariyoshi N, Kotani A, Ishii I, Nakamura $\mathrm{H}$, Nakasa $\mathrm{H}$, Ida $\mathrm{M}$, Nakamura $\mathrm{H}$, Kimura $\mathrm{N}$, Kimura M, Hasegawa A, Kusu F, Ohmori S, Nakazawa $\mathrm{K}$, Kitada $\mathrm{M}$. Effects of continuous ingestion of green tea or grape seed extracts on the pharmacokinetics of midazolam. Drug Metab Pharmacokinet. 2004; 19(4):280-9.

54. Carrasco-Pozo C, Mizgier ML, Speisky H, Gotteland M. Differential protective effects of quercetin, resveratrol, rutin and epigallocatechin gallate against mitochondrial dysfunction induced by indomethacin in Caco- 2 cells. Chem Biol Interact. 2012; 195(3):199-205.

55. Knudsen JF, Sokol GH. Potential glucosaminewarfarin interaction resulting in increased international normalized ratio: case report and review of the literature and MedWatch database. Pharmacotherapy. 2008; 28(4):540-8.

56. Mayo Clinic. Mayo Foundation for Medical Education and Research; (c) 1998-2017 [cited 2016 Dec 27]. Available from: https://www. mayoclinic.org

57. Dresser GK, Wacher V, Wong S, Wong HT, Bailey DG. Evaluation of peppermint oil and ascorbyl palmitate as inhibitors of cytochrome P4503A4 activity in vitro and in vivo. Clin Pharmacol Ther. 2002; 72(3):247-55.

58. Posadzki P, Watson LK, Ernst E. Adverse effects of herbal medicines: an overview of systematic reviews. Clin Med (Lond). 2013 Feb; 13(1):7-12.

59. Posadzki P, Watson L, Ernst E. Herb-drug interactions: an overview of systematic reviews. $\mathrm{Br} \mathrm{J}$ Clin Pharmacol. 2013; 75(3):603-18.

60. Duvic M, Reisman M, Finley V, Rapini R., DiLuzio N., Mansell PWA. Glucan-induced keratoderma in acquired immunodeficiency syndrome. Arch Dermatol. 1987; 123(6):751-6.

61. Bártíková H, Skálová L, Dršata J, Boušová I. Interaction of anthocyanins with drug-metabolizing and antioxidant enzymes. Curr Med Chem. 2013; 20(37):4665-79.

62. Hou XL, Takahashi K, Kinoshita N, Qiu F, Tanaka K, Komatsu K, Takahashi K, Azuma J. Possible inhibitory mechanism of Curcuma drugs on CYP3A4 in 1alpha,25 dihydroxyvitamin D3 treated Caco-2 cells. Int J Pharm. 2007; 337(1-2):169-77.

63. Hou XL, Takahashi K, Tanaka K, Tougou K, Qiu F, Komatsu K, Takahashi K, Azuma J. Curcuma drugs and curcumin regulate the expression and function of P-gp in Caco-2 cells in completely opposite ways. Int J Pharmaceutics. 2008; 358(1-2):224-9.
64. Bamba Y, Yun YS, Kunugi A, Inoue H. Compounds isolated from Curcuma aromatica Salisb. inhibit human P450 enzymes. J Nat Med.2011;65(3-4):583-7.

65. Bahramsoltani R, Rahimi R, Farzaei MH. Pharmacokinetic interactions of curcuminoids with conventional drugs: A review. J Ethnopharmacol. 2017; 209:1-12.

66. Li Y, Revalde J, Paxton JW. The effects of dietary and herbal phytochemicals on drug transporters. Adv Drug Deliv Rev. 2017; 116:45-62.

67. Đaković Švajcer K. Međudelovanja lekova, hrane i suplemenata/interactions of medicinal products, food and supplements. (on Serbian), Alfagraf, Petrovaradin, 2016. 


\section{Interakcije lekova sa dijetetskim suplementima}

Kornelia W. Đaković Švajcer

Katedra za farmakologiju, toksikologiju i klinicku farmakologiju, Medicinski fakultet, Univerzitet u Novom Sadu, Novi Sad, Srbija

\section{KRATAK SADRŽAJ}

Uvod: Široka primena lekova kod pacijenata sa različitim nutritivnim statusom, dijetetskim navikama, načinom ishrane i suplementima u dijeti stvara mogućnost za nastanak potencijjalno neograničenog broja interakcija lekova i hrane. lako se broj interakcija i permutacija može čintiti porazan, a proporcija klinički značajnih manifestacija nije jasna, u klinici se ne sme zanemariti njihova potencijalna opasnost.

Tema: Mnogi lekovi sadrže sastojke koji stupaju u reakciju sa organizmom čoveka na različite načine. Dijetetske navike i životni stil mogu ponekad značajno uticati na delovanje lekova. Interakcije lekova i dijetetskih suplemenata mogu imati značajan uticaj na uspeh terapije. Na ovu vrstu interakcija se često zaboravlja kada se propisuju lekovi, tako da pacijent obično nije ni svestan da njegove navike u ishrani, sa datim lekovima, mogu naškoditi njegovom zdravlju.

Zaključak: Rezultat ovih interakcija u odnosu na delovanje lekova može biti pozitivan i negativan, ali često je veoma značajan.

Ključne reči: interakcije, dijetetski suplementi, metabolizam lekova, efekti lekova 